\title{
IDENTIFICATION OF BANANA VARIETIES WITH RESISTANCE TO NEMATODES IN RWANDA
}

\author{
S. V. GAIDASHOVA, B. UWIMPUHWE and E.B. KARAMURA ${ }^{1}$ \\ Institut des Sciences Agronomiques du Rwanda (ISAR), ISAR-Kibungo, Ngoma district, Rwanda \\ ${ }^{1}$ Bioversity International, P. O. Box 24384, Kampala, Uganda
}

\begin{abstract}
Plant parasitic nematodes are recognised as a significant factor limiting banana (Musa spp.) production worldwide. Identification of banana varieties with resistance to nematodes may be the best option for sustainable nematode management. The objective of the experiment was to evaluate banana varieties with resistance to nematodes. Six varieties FHIA01, FHIA03, FHIA23, FHIA25, Gros Michel and Kamaramasenge were evaluated with Calcutta 4 as reference genotype. Data were recorded on root damage and nematode population densities at 6 and 9 months after planting, at flowering and at harvest for the two cycles. Results indicated that Gros Michel, Kamaramasenge and Calcutta 4 had lower density of Pratylenchus goodeyi and least root damage. They may be considered as partially resistant to this nematode. Contrary, FHIA 25 and FHIA 23 contained the highest density and root damage and were the most susceptible to Pratylenchus goodeyi. Kamaramasenge, Gros Michel and FHIA 25 supported less than one thousand nematodes of Meloidogyne javanica per $100 \mathrm{~g}$ fresh root weight, however, this was not significantly different from other varieties which supported higher number of this nematode. The level of recorded build-up of $M$. javanica did not allow deciding with certainty about the status of resistance of the tested banana varieties to this nematode.
\end{abstract}

Key Words: Gros Michel, host plant resistance, Kamaramasenge, IPM, Musa spp.

\section{RÉSUMÉ}

Les nématodes parasitaires sont reconnus comme un facteur significatif limitant la production mondiale de la banane (Musa spp). L’identification de variétés de banane avec la résistance aux nématodes peut être la meilleure option pour la gestion viable de nématode. L'objectif de l'expérience était d'évaluer les variétés de banane avec la résistance aux nématodes. Six variétés FHIA01, FHIA03, FHIA23, FHIA25, Gros Michel et Kamaramasenge ont été évalués avec Calcutta 4 comme génotype de référence. Les données ont été enregistrées sur les dommages de racines et les densités de population de nématode à 6 et 9 mois après la plantation, à fleurir et à la moisson pour les deux cycles. Les résultats ont indiqué ce Gros Michel, Kamaramasenge et Calcutta 4 ont de densité plus basse que de Pratylenchus goodeyi et moins les dommages de racine. Ils pourraient être considérés comme partiellement résistant à ce nématode. Le contraire, FHIA 25 et FHIA 23 ont contenu la plus haute densité et les dommages de racine et étaient le plus susceptible à Pratylenchus goodeyi. Kamaramasenge, Gros Michel et FHIA 25 soutenu moins qu'un mille nématodes de Meloidogyne javanica par $100 \mathrm{~g}$ le poids fondamental frais, cependant, ceci n'était pas significativement différent des autres variétés qui ont resistés le plus haut nombre de ce nématode. Le niveau d'accumulation enregistrée de $M$. javanica n'a pas permis de décider avec la certitude du statut de résistance des variétés de banane essayées à ce nématode.

Mots Clés: Gros Michel, accueillir la résistance de plante, Kamaramasenge, IPM, Musa spp. 


\section{INTRODUCTION}

Worldwide, banana production is constrained by parasitic nematodes (Davide, 1996). Nematode infestation results in root damage of plants, reduced water and nutrient uptake with severe infestation leading to stunted growth and reduced yields and toppling (Speijer and De Waele, 1997). Globally, Radopholus similis, Pratylenchus coffeae, Pratylenchus goodeyi and Helicotylenchus multicinctus cause serious damage to banana (Bridge, 1993).

In Rwanda, where banana is an important food and cash crop, two nematode species, $P$. goodeyi and Meloidogyne spp., have been reported to cause significant damage to root system of banana (Okech et al., 2002; Gaidashova et al., 2004). Nematode management has so far been through rotation, replanting and mulching as well as nematicide application (Gowen, 1993). Breeding of banana varieties with resistance to nematodes may be the most appropriate option for sustainable nematode management.

Previous studies have identified the sources of resistance to nematodes within banana germplasm (Wehunt et al., 1978; Price 1994; Stoffelen et al., 1999). Some Musa genotypes have shown different levels of resistance to Radopholus similis (Gowen, 1996). However, these genotypes have not been investigated for resistance to other important nematode species like P. goodeyi and Meloidogyne spp., which are major banana parasitic species in East African highlands. The objective of the experiment was to identify banana varieties resistant to $P$. goodeyi and $M$. javanica.

\section{MATERIAL AND METHODS}

The experiment was conducted at Rubona station in the south of Rwanda, $105 \mathrm{~km}$ south of Kigali, at 1750 meters above sea level (masl) and receiving $1170 \mathrm{~mm}$ of rain annually. The dominant soil type is Acrisols (ISSS WGRB (FAO), 1998).

The study was carried out during 2002 to 2005 in a field previously occupied by banana heavily infested with nematodes $P$. goodeyi and $M$. javanica. Six soil and banana root samples were taken in the field to determine natural nematode population densities prior to trial installation. $P$. goodeyi averaged 192955 nematodes per 100g fresh roots and 61 nematodes per $100 \mathrm{ml}$ soil. $M$. javanica was present only in soil samples (29 juveniles per $100 \mathrm{ml}$ soil). Identification of nematodes to species level from Rubona station fields was done at Biosystematics Division of Plant Protection Research Institute, Pretoria, South Africa in December 2001.

The experimental material consisted of seven varieties: four FHIA varieties - FHIA01, FHIA03, FHIA23 and FHIA25 obtained from Bioversity International (formally INIBAP) via Du Roi tissue culture laboratory, South Africa; Gros Michel from Institut de Recherches Agronomiques et Zootechniques (IRAZ), Burundi and Kamaramasenge and Calcutta 4 from ISAR, Rubona. The first two lots of varieties were tissue culture plants and the third lot was conventional planting material. Selection of FHIA varieties for this trial was based on their superior yield characteristics, while Calcutta 4 was used as a reference resistant variety. Gros Michel and Kamaramasenge are local dessert varieties.

A split plot design was used with treatments as follows: main plots consisted of nematicide application (with and without) and sub-plots consisted of varieties. Each plot contained 6 plants of each genotype/variety and was replicated 3 times.

Nematicide Carbofuran 5G was used at the rate of $60 \mathrm{~g}$ per plant at planting and followed by application of the same amount after 6 monthly intervals. Cattle manure was applied at rate of 20 kg per hole at planting. No mineral fertilisers were used in this trial. All plots were mulched with grasses of Tripsacum sp. twice a year before the beginning of dry season (in June and January). Three suckers were maintained for each banana mat. De-suckering and weeding were done regularly depending on necessity.

Data were recorded on root damage and nematode population densities at 6 and 9 months after planting (MAP), at flowering, and at harvest for two production cycles. Flowering time was recorded at the emergence of the flag leaf and sampling was done within 14 days after. Harvest was done when the fruits' ridges were rounded. Banana root damage and nematode population density were observed on mother plants at 6 and $9 \mathrm{MAP}$ and flowering and on young (less than 50 
cm height) suckers detached from the mother plant at harvest. Roots were sampled according to the procedure described by Speijer and De Waele (1997). Root necrosis index and percentage of dead roots were used as indicators of root damage. $P$. goodeyi and $M$. javanica juveniles population densities were determined from a sample of $5 \mathrm{~g}$ and recalculated per $100 \mathrm{~g}$ of fresh root weight. Nematode extraction was done using modified Baerman funnel (Speijer and De Waele, 1997). Nematode population density and root damage served as indicators of the level of resistance or tolerance of each variety.

Data were analysed using Genstat Release 4.3 software. Two-way analysis of variance (ANOVA) and least significant difference (LSD) tests were performed for variables with significant difference of means.

\section{RESULTS}

Root damage as percentage of dead roots are presented in Table 1. At 9 MAP, Gros Michel, Calcutta 4 and Kamaramasenge had significantly $(\mathrm{P}<0.001)$ less dead roots compared to other varieties (Table 1). At Harvest 1, FHIA 23 had higher $(\mathrm{P}<0.05)$ percentage of dead roots compared to other varieties. For the rest of observations, there was no significant difference in dead roots among the varieties. Gros Michel and the reference variety, Calcutta 4 , had very few dead roots compared to FHIA varieties, though the difference was not significant $(\mathrm{P}<0.05)$.

Varieties expressed significant differences in percentage of root necrosis at $9 \mathrm{MAP}$, flowering 1 , harvest 1 and flowering $2(\mathrm{P}<0.001$ for all observations) (Table 2). These differences were not significant at the early stages of the trial (6 MAP). Calcutta 4 had the least root necrosis index across all observations. It was followed by Gros Michel and Kamaramasenge. FHIA 23 had highest root necrosis along all observations, followed by FHIA 03, FHIA 25 and FHIA01.

There were highly significant differences $(\mathrm{P}<0.001)$ in $P$. goodeyi population densities from 6 MAP to harvest 2 (Table 3). Calcutta 4 contained the least nematode population densities of $P$. goodeyi at all observations; this was followed by Gros Michel and Kamaramasenge. FHIA 23

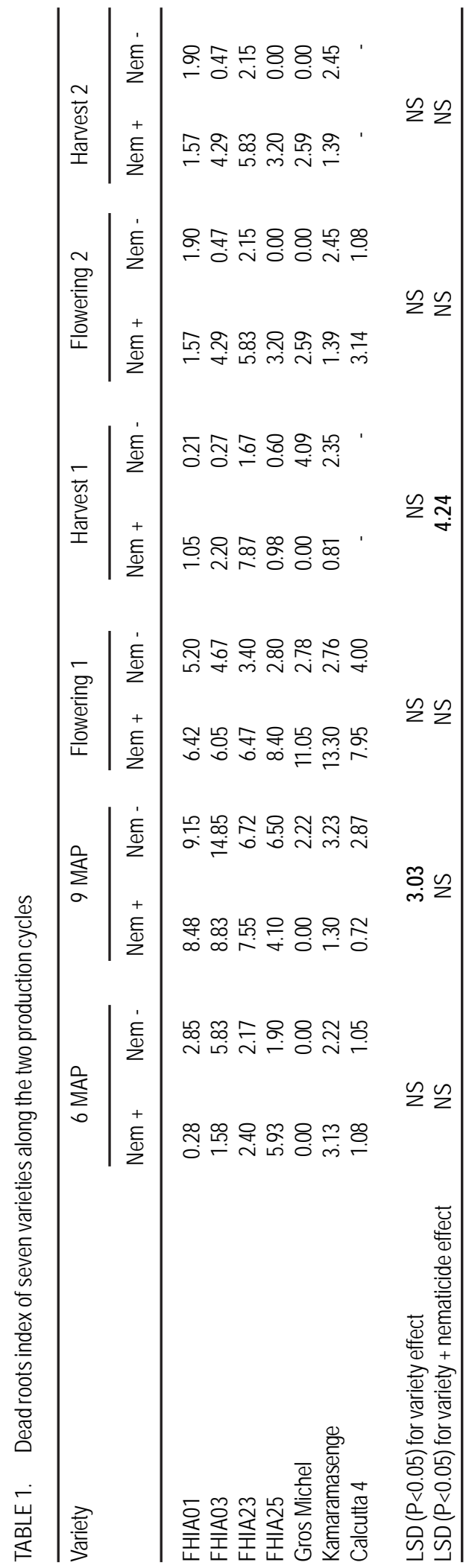




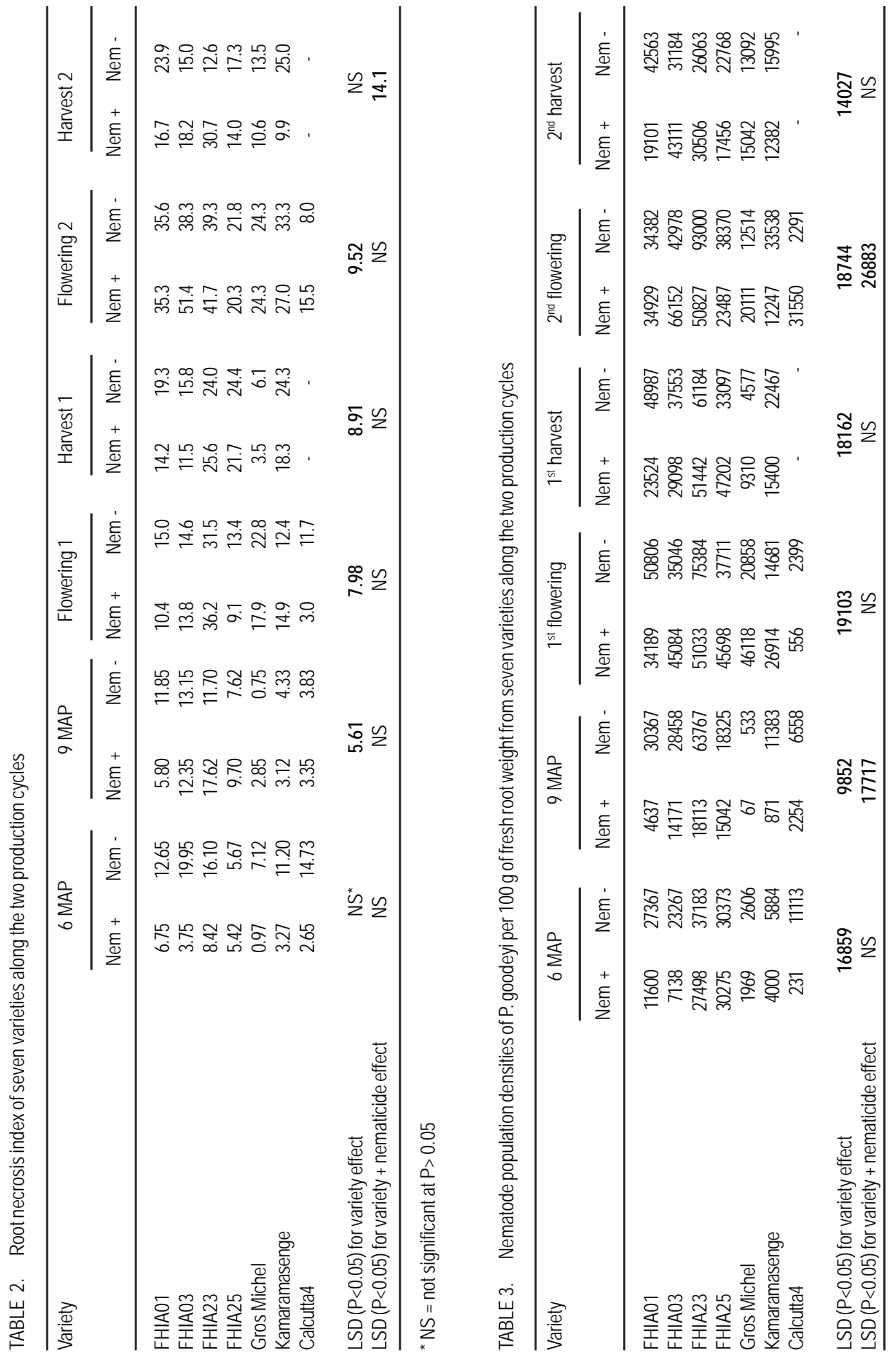


and FHIA 25 had highest population densities at all stages.

No significant differences $(\mathrm{P}>0.05)$ were observed in $M$. javanica population densities among the varieties at 6 and 9 MAP, flowering 1 and harvest 1 . At flowering 2, Calcutta 4 had a higher $(\mathrm{P}<0.05)$ number of juveniles (Table 4$)$ than those of the other varieties, however, at harvest 2, Gros Michel and FHIA 23 contained a higher number of juveniles than those of the other varieties in nematicide free plots.

\section{DISCUSSION}

Terms "resistance" and "susceptibility" referred to nematodes are used when a host plant suppresses (resistance) or allows (susceptibility) nematode development and reproduction. In case of susceptibility, a host plant may suffer little injury (tolerance) or much injury (sensitivity), even when relatively lightly infected with nematodes (De Waele, 1996). There exist completely, highly and partially resistant genotypes supporting, respectively, no, little or an intermediate level of nematode reproduction (De Waele, 1996). In this regards, root damage due to nematodes and their population densities help to establish the status of resistance of Musa cultivars to nematodes (Collingborn and Gowen, 1998; Speijer et al., 1999).

In this study, dead roots did not show significant differences among the varieties tested in contrast to root necrosis index and nematode population densities. Rajab et al. (1999) reported that environment affected proportion of dead roots more substantially than the genotype, while Speijer and De Waele (2001) observed substantial differences in proportion of dead roots between various Musa genotypes independently on location. Root necrosis index and nematode population densities were the most discriminate in this study in showing the difference in host reaction by banana varieties to nematodes. Possibly, the proportion of dead roots was affected by other factors as seasonal rainfall and soil properties which might have influenced growth and survival of roots resulted from varietyspecific adaptation to soil and climate conditions (Price, 1995). 
The nematicide Carbofuran was used in commercial banana production (Tomlin, 1994). However, the recommendations regarding the use of this chemical to control P. goodeyi are lacking. The fact, that in nematicide applied plots a lot of nematodes were recorded indicates that Carbofuran was not very effective against $P$. goodeyi and $M$. javanica.

In previous studies, Gros Michel and Calcutta 4 were tested for their resistance to Radopholus similis (Speijer and Ssango, 1999; Speijer et al., 1999). They had much lower damage and population densities. They may be considered as partially resistant to $R$. similis. In our study, Calcutta 4, Gros Michel and Kamaramasenge had consistently lower number of $P$. goodeyi along trial observations and had least root necrosis and percentage of dead roots. These three varieties may be considered partially resistant to this nematode. Contrary, FHIA 25 and FHIA 23 contained the highest nematode densities and root damage and were the most susceptible to $P$. goodeyi and root damage due to this nematode. FHIA 01 and FHIA 03 had intermediate position.

Varieties expressed variable reaction to $M$. javanica and only few significant differences were observed at flowering 2 (Table 4). Some evidence for higher infestation of Gros Michel and Calcutta 4 by $M$. javanica was shown during the two production cycles. However, due to low infestation levels of banana roots by this nematode, no consistent data were obtained from this trial. The level of recorded build-up of $M$. javanica did not allow deciding with certainty about the status of resistance of the tested banana varieties to this nematode. For the two species of nematodes present in the field, the establishment of $M$. javanica was much lower compared to that of $P$. goodeyi, which was dominant in nearly all plots irrespective of nematicide treatment. Possibly, the dominance of $P$. goodeyi suppressed the build up of $M$. javanica as this phenomenon was reported for other plant parasitic nematodes, e.g. $R$. similis and $M$. incognita (Santo and Davide, 1982). Other reasons may be non-homogenous distribution of $M$. javanica within the experimental field or that some species require long time for establishment (Speijer and Ssango, 1999). However, it is less likely as the population densities of M. javanica from this trial were similar to those reported on farm in old banana fields (Gaidashova et al., 2004). None of the six varieties tested can be considered as fully resistant either to $P$. goodeyi, or M. javanica. Gros Michel and Kamaramasenge are considered to be partially resistant to $P$. goodeyi, and at similar level as Calcutta 4, the reference cultivar. From this study, FHIA 25 and FHIA 23 were considered as susceptible to P. goodeyi while. FHIA 01 and FHIA 03 were moderately susceptible to $P$. goodeyi. . Calcutta 4, Gros Michel and Kamaramasenge may be used in further screening experiments as reference cultivars to evaluate resistance to nematodes and FHIA 25 and FHIA 23 may serve as susceptible checks. Further research should focus on screening wider germplasm for resistance to $P$. goodeyi and $M$. javanica.

\section{ACKNOWLEDGEMENT}

The authors thank Bioversity International and Institut de Recherche Agronomique et Zootechnique, Burundi for providing banana plantlets for this experiment and the United States Agency for International Development for funding this research via the Agricultural Technology Development and Transfer project. Bioversity International has kindly facilitated the exercise of writing this manuscript.

\section{REFERENCES}

Bridge, J. 1993. Worldwide distribution of the major nematode parasites of bananas and plantains. In: Biological and integrated control of highland banana and plantain pests and diseases. Proceedings of a Research Coordination Meeting. C.S. Gold and B. Gemmil (Eds), pp. 185-198. Cotonou, Benin, 12-14 November 1991.

Collingborn, F. M. B. and Gowen, S. R. 1998. Screening Indian cultivars of Musa for resistance or tolerance to Radopholus similis and Pratylenchus coffeae. In: Proceedings of International Symposium on banana in sub-tropics. Acta Horticulturae 490:369-371.

Davide, R.G.. 1996. Overview of nematodes as a limiting factor in Musa production. In: 
Proceedings of the workshop on new frontiers in resistance breeding for nematode, fusarium and Sigatoka, 2-5 October 1995, Kuala Lumpur, Malaysia. Frison, E.A., .Horry, J.P. and De Waele, D. (Eds.), pp. 27-31. INIBAP, Montpellier, France.

De Waele, D. 1996. Plant resistance to nematodes in other crops: relevant research that may be applicable to Musa In: Proceedings of the workshop on new frontiers in resistance breeding for nematode, fusarium and Sigatoka, 2-5 October 1995, Kuala Lumpur, Malaysia. Frison, E.A., .Horry, J.P. and De Waele, D. (Eds.), pp. 27-31. INIBAP, Montpellier, France.

Gaidashova, S.V., Okech, S., Van den Berg, E., Marais, M., Gatarayiha, C. M. and Ragama P.E. 2004. Plant-parasitic nematodes in banana-based farming systems in Rwanda: species profile, distribution and abundance. African Plant Protection 10(1):27-33.

Gowen, S. R. 1993. Yield losses caused by nematodes to different banana varieties and some management techniques appropriate for farmers in Africa. In: Biological and integrated control of highland banana and plantain pests and diseases. Proceedings of a Research Coordination Meeting. Gold, C.S. and Gemmil, B. (Eds.), pp. 199-208. Cotonou, Benin, 12-14 November 1991.

Gowen, S.R. 1996. The source of nematode resistance, the possible mechanisms and the potential for nematode tolerance in Musa. In: Proceedings of the workshop on new frontiers in resistance breeding for nematode, fusarium and Sigatoka, 2-5 October 1995, Kuala Lumpur, Malaysia. Frison, E.A., .Horry, J.P. and De Waele, D. (Eds.), pp. 27-31. INIBAP, Montpellier, France.

ISSS Working Group Reference Base, 1998. Word Reference Base for Soil Resource: Keys to Reference Soil Groups of the World. World Soil resource Report No 84, FAO, Rome, Italy. on line: ftp://ftp.fao.org/agl/agll/docs/ wsrr84e.pdf ; consulted on the 7.02.2008).

Price, N. 1994. Field trial evaluation of nematode susceptibility in Musa. Fundamental and Applied Nematology 17: 391-396.
Price, N.S. 1995. Banana morphology - part I: roots and rhizomes. In: Gowen, S. (Ed.), 179-189. Bananas and plantains, Chapman \& Hall, UK. Rajab, K.A., Salim, S.S. and Speijer, P.R. 1999. Plant-parasitic nematodes associated with Musa in Zanzibar. African Plant Protection 5(2): 105-110.

Okech, S. H., Gaidashova, S. V., Gold, C. S., Gatarayiha, C. and Ragama, P. 2002. Banana pests and diseases in Rwanda: A Participatory Rural Appraisal and Diagnostic Survey observations. In: Proceedings of the Integrated Pest Management Symposium, 8 - 12 September 2002, Kampala. Adipala et al. (Eds.), pp. 162-170. NARO/ Makerere University, Kampala, Uganda.

Santo, W. and Davide, R.G. 1982. Interrelationships of Radopholus similis and Meloidogyne incognita in banana. Phillippine Phytopathology 18: 22 - 33.

Speijer, P.R. and De Waele, D. 1997. Screening of Musa germplasm for resistance and tolerance to nematodes. INIBAP Technical Guidelines, No 1, pp. 47.

Speijer, P.R., Boonen, E., Vuylsteke, D. Swennen R.L. and De Waele, D. 1999. Nematode reproduction and damage to Musa sword suckers and sword sucker derived plants. Nematropica 29 (2):193-203.

Speijer, P. R. and Ssango, F. 1999. Evaluation of Musa host plant response using nematode densities and damage indices. Nematropica 29(2):185-192.

Speijer, P.R. and De Waele, D. 2001. Nematodes associated with East African highland cooking bananas and cv. Pisang Awak (Musa spp.) in Central Uganda. Nematology 3(6): 535-541.

Stoffelen, R., Verlinden, R., Ngo Thi Xuyen, Swennen, R. and De Waele, D. 1999. Screening of Papua New Guinea bananas to root-lesion and root-knot nematodes. Infomusa 8 (1): 12-15.

Tomlin, C. 1994. The pesticide manual. Tomlin, C. (Ed.). $10^{\text {th }}$ edition, British Crop Protection Council, UK.

Wehunt, E. J., Hutshinson, D. J. and Edwards D.I. 1978. Reactions of banana cultivars to the burrowing nematode. Journal of Nematology 10: 368-370. 